\title{
THE ASEAN FREE TRADE AREA (AFTA) AND ITS COMPATIBILITY WITH THE GATT/WTO
}

\author{
Alberta Fabbricotti
}

\section{INTRODUCTION}

The Asian economic crisis has caused growing concern, especially considering the spectacular economic development of South and East Asian countries of the last two decades, and has threatened the process of integration under construction in that region. ${ }^{1}$ In this paper attention is primarily focused on the Association of South East Asian Nations (ASEAN) ${ }^{2}$ and, more specifically, on the ASEAN Free Trade Area (AFTA), which symbolises the recent response of the Southeast Asian countries to other, more advanced, instances of regional economic integration, and to the globalization process.

AFTA represents a challenge also for ASEAN after the unsuccessful programmes for the expansion of trade amongst ASEAN economies and prior to the formation of the free-trade area. ${ }^{3}$

\footnotetext{
* Institute of International Law, University of Rome 'La Sapienza'. E-mail: alberta.fabbricotti@ uniromal.it

1 For a survey of the Asian financial and economic crisis, see, among others, S.CLAESSENS and T.GLAESSNER, Are financial sector weaknesses undermining the East Asian miracle? (Washington: World Bank, 1997); P.DIBB, D.D.HALE and P.PRINCE, 'The strategic implications of Asia's economic crisis', 40 Survival 2 (1998) 5-26; SHALENDRA D. SHARMA, 'Asia's economic crisis and the IMF', 40 Survival 2 (1998) 27-52; 'Trade Implications of the East Asian Crisis', and 'International Financial Instability and the East Asian Crisis', in: (UNCTAD) Trade and Development Report 1998, chapters II and III, respectively; 'Asia and the Pacific', in: (UNCTAD) World Investment Report 1998: Trends and Determinants, chapter VII; D.K.BROOKS and M.QUEISSER (eds.), Financial liberalisation in Asia: analysis and prospects (Paris: OECD, 1999); A.McINTYRE, 'Institutions and investors: the politics of the economic crisis in Southeast Asia', 55 International Organization (2001) 81-122. ${ }_{2}$ ASEAN comprises Brunei Darussalam, Cambodia, Indonesia, Laos, Malaysia, Myanmar, Philippines, Singapore, Thailand, and Vietnam.

${ }^{3}$ Before presenting AFTA, it is appropriate to introduce the concept of the ASEAN Preferential Trading Arrangements (PTA) which was the predecessor of AFTA. The 1976 Declaration of ASEAN Concord (in M. HAAS (ed.), Basic Documents of Asian Regional Organizations, Dobbs Ferry, N.Y.: Oceana Publ. (1979), Vol.6 at 321); ASEAN Documents Series 1967-1988 p.36), the 1976 Treaty of Amity and Cooperation in Southeast Asia (Basic Documents etc. Vol.6 at 316; ASEAN Documents
} 
It therefore seems important, after a basic description of what AFTA actually is and an explanation of what it entails, to determine its place within the multilateral trading system and, in particular, its compliance with the rules of GATT/WTO.

The notification of the establishment of AFTA and its provisions under the Enabling Clause, which contains a significant relaxation of the conditions for the creation of free-trade areas or customs unions among developing countries, has not given rise to objections. ${ }^{4}$ Thus, the mechanism of Article XXIV of GATT, which concerns the assessment of the conformity of regional integration arrangements with the multilateral trading system, may be presumed not to apply in the case of AFTA. A similar reasoning could arguably be followed with regard to a future decision on AFTA compatibility with the rules of the General Agreement on Trade in Services (GATS). In the latter case, however, recourse to the Enabling Clause seems redundant: a special set of rules in favour of developing countries is here provided by Article $\mathrm{V}$ in the GATS dealing with economic regional integration in the field of trade

etc. at 39) and the 1976 Agreement on the Establishment of the ASEAN Secretariat (Basic Documents etc. Vol.6 at 345; ASEAN Documents etc. at 165), are among the fundamental documents relating to the launch of economic integration among ASEAN member states, a policy promoted at the Summit of Den Pasar (Bali) in February 1976. Of particular importance is the second of these documents that became, notwithstanding its programmatic nature, the point of departure for increased economic co-operation among the member states since then. The ideas contained in the Treaty of Amity and Cooperation aiming at breathing new life into co-ordination in the economic field were observed and followed by the adoption in 1977 of the Agreement on the PTA (Basic Documents etc. Vol.6 at 354; ASEAN Documents etc. at 293) and the approval of several projects of industrial development). The 1977 Agreement granted the ASEAN member states the opportunity to grant preferences to one another on a selective basis. During the Summit of Manila (1987), the ASEAN Heads of Government signed four new agreements to (1) put half of intra-ASEAN trade under the existing ASEAN PTA after five years (Protocol on Improvements on Extension of Tariff Preferences under the ASEAN Preferential Trading Arrangement (ASEAN Documents Series 1967-1988 at 302); (2) expand industrial joint ventures (Revised Basic Agreement on ASEAN Industrial Joint Ventures, ibid. at 281); (3) freeze and gradually reduce non-tariff barriers to intra-ASEAN trade (Memorandum of Understanding on Standstill and Rollback on Non-Tariff Barriers among ASEAN countries, ibid. at 310) and (4) encourage investments by offering an investment guarantee agreement (Agreement for the Promotion and Protection of Investments, ibid. at 288). The reduction of tariffs became the most important and widely used instrument of the PTA and it evolved from a product-by-product means to a wider range of products. The PTA, however, failed to significantly increase intra-ASEAN trade. According to most analyses, the reason for this failure was to be found in the relatively small tariff cuts offered and in the extremely small number of products exchanged among the ASEAN countries, in comparison to total number of products traded by the ASEAN countries. See on this issue, infra, section 1.

${ }^{4}$ The Enabling Clause (Decision of CONTRACTING PARTIES of 28 November 1979 on differential and more favourable treatment, reciprocity and fuller participation of developing countries) provides an important exception to the general principle of most favoured nation (MFN) in favour of developing countries, inter alia facilitating agreements amongst those states for the mutual reduction or elimination of tariffs and non-tariff measures on a preferential basis. Text in L/4903, BISD 26S/203; www.wto.org. 
in services. Indeed, under its paragraph 3 developing countries are granted flexibility in observing the general requirements for an economic integration agreement as set out in paragraph 1. ASEAN Member States would be entitled, when notifying the ASEAN Framework Agreement on Services (AFAS), to resort to paragraph 3 in order to avoid in-depth scrutiny by the WTO.

The above reasoning is, however, debatable. First, doubt may be raised as to whether ASEAN Member States still fall within the category of developing countries. ${ }^{5}$ Indeed, there seems to be no ground for exempting ASEAN Members from compliance with Article XXIV of the GATT if at least certain of these Countries are considered as economically developed or in transition. ${ }^{6}$ Secondly, it is questionable whether the duty of notification under the Enabling Clause represents an alternative to the notification requirement of Article XXIV, paragraph 7 of the GATT. This question has never been seriously examined before; it is necessary to collect the relevant data, if not from the flexible monitoring system of WTO, then at least from the ASEAN Members' behaviour.

\section{THE ESTABLISHMENT OF THE AFTA}

The sudden revival of economic regionalism, especially the developments in the European Union and the conclusion of the North-American Free Trade Agreement (NAFTA), pushed the Heads of State and Government of ASEAN at their meeting at Singapore in 1992 officially to announce the creation of the ASEAN Free Trade Area (AFTA). ${ }^{7}$

\footnotetext{
5 See also P.J.DAVIDSON, 'ASEAN: The legal framework for its trade relations', 49 International Journal (1994) at 598 and 607. But the contrary has been equally asserted in respect of the period between 1970 and 1979. See P.BURNS, 'The Association of South East Asian Countries (ASEAN)', in J.JAMAR (ed.), Intégrations régionales entre pays en voie de développement (Cahiers de Bruges No.41, Bruges: Tempelhof, 1982), at 20, who states that "[t]he ASEAN States can be correctly considered as developing countries".

6 P.J.DAVIDSON, loc.cit. n.5 at 607-608 rightly remarks that: "[t]he Enabling Clause provides for 'regional or global arrangements entered into amongst less-developed contracting parties'. Although the clause allows a developed country to give preferences to trade coming from developing countries, it does not permit the reverse, that is, preferences given by a developing country to trade coming from a developed country. Moreover, any preferences given have to be non-discriminatory 'in accordance with the Generalized System of Preferences'. Thus, it would appear that a developed country cannot participate in a free trade area on the basis of the Enabling Clause". One could argue that, as far as trade in services is concerned, this preclusion would only partly concern the conformity of a regional agreement with the multilateral rules on trade, because paragraph 3 of Article $\mathrm{V}$ of the GATS makes a distinction within the category of regional agreements liberalising trade in services: those including developing countries among the participants (letter $a$ ) from those involving only developing countries (letter $b$ ). As a result, it is admitted that a certain flexibility in regarding the conditions set out in paragraph 1 be granted to "mixed" agreements.

7 On East-Asian reactions to the challenge of the European Union's 1992 programme, the Canada-US Free Trade Agreement and the efforts to include Mexico into the latter, see H.DiCHTER, 'Legal
} 
The new framework of regional economic co-operation, as conceived at the Singapore Summit, is based on three instruments: ${ }^{8}$ The Singapore Declaration, which represents the first of these instruments, summarises, in a number of programmatic chapters, the understandings gained in the different fields of the activity of the Association. In the field of economic co-operation, the Declaration not only announces the establishment of AFTA, but also determines in detail its aims and its essential working rules; it further outlines instruments to accompany and complement the free-trade area and to deal, for instance, with the search for new models of industrial development, the liberalization of the movement of capital, the improvement of transport, communications, postal services and telecommunications, the strengthening of co-operation with other countries and international organizations, and the promotion of inter-ASEAN investments. ${ }^{9}$

AFTA is only an aspect, although undoubtedly the most relevant, of the programme of economic co-operation planned in the second document, the Framework Agreement on Enhancing ASEAN Economic Co-operation. ${ }^{10}$ Article 2(A) of this Agreement envisages the realization of the free-trade area within 15 years and, to this end, provides for a Council consisting of the ASEAN Economic Ministers to be charged with its effective implementation. The purpose of the AFTA, as defined in the Singapore Declaration, is the reduction of tariffs between Member States to a level below five per cent through the application of a Common Effective Preferential Tariff (CEPT) scheme.

The CEPT is determined on the basis of a scheme contained in the third document adopted in Singapore, the so-called CEPT-AFTA Agreement. ${ }^{11}$ According to the definition supplied in Article 1 of this Agreement, the CEPT applies to products originating from ASEAN Member States. Paragraphs 4 and 5 of Article 2 specify that a product is to be considered of ASEAN origin if at least $40 \%$ of its content originates from any of the ASEAN Member States and that the schedule fixed for tariff reduction is automatically applicable to all manufactured goods, including capital and processed agricultural products. From the wording of these provisions, in connection with the

\footnotetext{
implications of an Asia-Pacific Economic Grouping', 16 University of Pennsylvania Journal of International Business Law (1995) 99-154; R.POMFRET, 'Regionalism in Europe and the Asia Pacific economy', in P.DRYSDALE and D.VINES (eds.), Europe, East Asia and APEC (Cambridge UP 1998) at $54-55$.

${ }^{8}$ On the Singapore Summit and the agreements adopted there, see P.KENEVAN and A.WINDEN, 'Flexible free trade: the ASEAN Free Trade Area', 34 Harvard International Law Journal (1993) 224-240.

9 Singapore Declaration of 28 January 1992, 31 ILM (1992) 498; ASEAN Documents Series 1991 1992 p.16.

10 Agreement of 28 January 1992, 31 ILM (1992) 506; ASEAN Documents Series 1991-1992 p.7.

11 Agreement on the Common Effective Preferential Tariff (CEPT) Scheme for the ASEAN Free Trade Area (AFTA) of 28 January 1992, 31 ILM (1992) 514; ASEAN Documents Series 1991-1992 p.11.
} 
definition of "agricultural products" in Article 1 paragraph $7,{ }^{12}$ it follows that both primary agricultural products and those that have undergone simple processing yet have retained their original form are excluded from tariff reduction.

As regards the list of products covered by tariff reduction, the system shows a large margin of flexibility. This becomes evident through some important exceptions. One of these is to be found in Article 2, paragraph 3 of the CEPT-AFTA Agreement, according to which a Member State may be exempted for a limited time from including a certain product in the list if that State is not yet ready to include it. Another exception is provided by the escape clause contained in Article 6, under which tariff reduction can be suspended when the import of a product covered by the CEPT scheme increases to such proportions as to cause (or threaten to cause) serious prejudice to the national production of the same item of goods.

What has been said so far refers to the primary free-trade agreement, that is to say, the Singapore Agreement of 1992. Some amendments have subsequently been introduced. These changes have been approved by the ASEAN Economic Ministers at Chiengmai (Thailand) in September 1994 and were couched in a legal form during the Summit Meeting at Bangkok in December $1995 .{ }^{13}$ It was decided to move up the implementation of AFTA from 1 January 2008 to 1 January $2003 .{ }^{14}$ Moreover, according to the new rules, primary agricultural products would automatically be subjected to the schedule of tariff reduction while those products temporarily excluded from the CEPT scheme in conformity with Article 2 paragraph 3 of the original CEPT-AFTA Agreement were to be gradually included in the scheme before 1 January $2000 .^{15}$

\footnotetext{
12 Art.1 para.7 CEPT-AFTA Agreement reads: “'AAgricultural products' means: (a) agricultural raw materials/unprocessed products covered under Chapters 1-24 of the Harmonised System (HS), and similar agricultural raw materials/unprocessed products in other related HS Headings; and (b) products which have undergone simple processing with minimal change in form from the original products".

${ }^{13}$ Bangkok Summit Declaration on the Progress of ASEAN, Vietnam's Membership, Greater Economic Cooperation and Closer Political Cooperation in International Fora, Bangkok 15 December 1995, 35 ILM (1996) 1063; ASEAN Document Series of 1994-1995, at www.aseansec.org. On content and relevance of these amendments see, inter alia, M.ARIFF, 'La liberalizzazione degli scambi e l'AFTA', in FONDAZIONE GIOVANNI AGNELLI (ed.), Rapporto ASEAN. Il futuro del Sud-Est Asiatico fra integrazione regionale e globalizzazione (Torino, 1996) at 51.

14 Art.1, Protocol to Amend the Framework Agreement on Enhancing ASEAN Economic Cooperation, Bangkok, 15 December 1995, at www.aseansec.org.; 6 AsYIL (1996) 501.

15 Art.1, Protocol to Amend the Agreement on the Common Effective Preferential Tariff Scheme for the ASEAN Free Trade Area, Bangkok, 15 December 1995, at www.aseansec.org.; 6 AsYIL (1996) 502. Finally, by virtue of a third Protocol (Protocol to Amend the Agreement on ASEAN Preferential Trading Arrangement, Bangkok, 15 December 1995, at www.aseansec.org.), the rules of origin which were at the basis of the tariff reductions of PTA (1977 Preferential Trading Arrangements) were replaced by those provided by the CEPT.
} 
Apparently, these amendments were considered essential to conforming AFTA to the requirements concerning the compatibility of treaties establishing economic regional organizations with the multilateral trading system. This topic will be discussed later.

To complete the description of AFTA, it appears important to observe the relationship of ASEAN and its Members with third states. Starting from 1976, a growing and closer partnership had developed with the World's great economic powers, ${ }^{16}$ such as Japan, ${ }^{17}$ the European Union ${ }^{18}$ and the USA. ${ }^{19}$ These commercial links have in the long run become vital for the economies of the ASEAN Member States. This is evidenced by the uninterrupted growth of trade to and from third countries during the period from the late 1970s to the mid-1990s. ${ }^{20}$ Hence, it is not surprising that the AFTA is unabashedly outward looking in its orientation.

Furthermore, efforts to increase trade within the ASEAN area before the establishment of the AFTA, such as the PTA (Preferential Trade Arrangements) and the projects of industrial development, ${ }^{21}$ were relatively unsuccessful in practice. ${ }^{22}$ Suffice it to consider that intra-ASEAN trade continued to cover only $30 \%$ or even less of all the trade of East Asia. ${ }^{23}$ Hence, an inward-looking ASEAN bloc would be disruptive and antithetical to the original purposes, as long as trade diversion were high and trade creation

${ }^{16}$ In fact, the starting point of this trend is to be found in the Declaration of ASEAN Concord (Supra n.3), Art. 6 of which exhorts the member states to "explore all avenues for close and beneficial cooperation with other states as well as international and regional organizations outside the region".

17 See F.JoYauX, L'Association des Nations du Sud-Est asiatique (ANSEA), (Paris: PUF, 1997) at 79 .

${ }^{18}$ For a survey of the ASEAN-European Union partnership, see U.HIEMENZ and R.J.LANGHAMMER (eds.), ASEAN and the EC - institutions and structural change in the European Community, (Singapore: ISEAS, 1988); R.FRID, The relations between the EC and international organizations. Legal theory and practice (The Hague-London-Boston: Kluwer, 1995) at 128; DJISMAN S.SIMANDJUNTAK, 'Le relazioni tra Unione Europea e ASEAN: passato, presente e futuro', in AGNELLI (ed.), op.cit. n.13 pp.67-82; M.CARBONIERO, 'Le relazioni UE-ASEAN: sviluppi recenti', 51 La Comunità Internazionale (1996) 590-600; CHIA SIOW YUE and JOSEPH TAN (eds.), ASEAN \& EU-forging new linkages and strategic alliances, (Singapore: ISEAS, 1997); R.J.LANGHAMMER, 'Europe's trade, investment and strategic policy interests in Asia and APEC', in P.DRYSDALE and D.VINES (eds.), op.cit. n.7 at 223.

19 See M.Y.PIERSON, 'East Asia: regional economic integration and implications for the United States', 25 Law and Policy in International Business (1994) 1161-1185.

20 Ibid. at 1173; P.GUERRIERI, 'Trade patterns and regimes in Asia and the Pacific', in V.K.AGGARWAL and C.E.MORRISON (eds.), Asia-Pacific crossroads: regime creation and the future of APEC (London: Macmillan, 1998) at 65.

${ }^{21}$ Supra n.3.

22 On this issue, see ARvind Panagariya, 'East Asia and the New Regionalism in world trade', 17 The World Economy (1994) at 825.

${ }^{23}$ The share of intra-ASEAN trade in world trade is controversial. G.R.SAXONHOUSE, 'Trading blocs and East Asia', in JAIME DE MELO and ARVIND PANAGARIYA (eds.), New dimensions in 
fairly minimal, and since a major goal of the AFTA is to attract direct foreign investments (DFI). ${ }^{24}$

According to most economic analyses, past attempts to promote intraASEAN trade have failed (failure marked by the stagnation of import-export within the area as compared to the impressive expansion of trade with countries outside ASEAN) because of a lack of a complementary nature in productive sectors within ASEAN (that is to say, the over-abundance of identical products) and, as a consequence, the small number of goods exchangeable among its Member States ${ }^{25}$ and the limited effect of tariff reductions on intra-ASEAN trade. ${ }^{26}$

The non-complementary nature of productive sectors, in addition to the great diversity among ASEAN Member States in terms of size, economic development, degree of industrialisation, political system and even in religion and culture, fully explains why the Association has never tried to follow a pattern of economic integration similar to the single market that brings together the Member States of the European Union. ${ }^{27}$ Yet, as will be demonstrated in the next section, the nature of the AFTA is ambitious: the different

regional integration (Cambridge: UP 1993) at 393, asserts that the amount of trade among member states is around $40 \%$ of ASEAN trade in total. This percentage seems modest anyhow compared with intra-area trade in Western Europe (European Union), which exceeds $70 \%$ of total trade. The same percentage, however, is high if compared to the intra-regional trade in North America. According to M.G.PLUMMER, 'ASEAN and institutional nesting in the Asia-Pacific: leading from behind in APEC', in V.K.AGGARWAL and C.E.MORRISON, op.cit. n.20 at 286: 'In 1994, approximately one fourth of ASEAN trade was intraregional, and even this figure is deceptive, as much of this trade is entrepôt in nature and flows through Singapore; if Singapore is excluded the figure falls to about 5 percent." According to ASEAN (www.aseansec.org), in 1997-1998 total extra-ASEAN exports amounted to approx. US\$250 billion, while total intra-ASEAN export was approx. US\$ 37 billion.

24 See M.G.PLUMMER, loc.cit. n.23 at 286 and 289.

25 According to SOMPONG SUCHARITKUL, 'ASEAN Society, a dynamic experiment for South-East Asian regional co-operation, 1 AsYIL (1991) at 117: "[O]utstanding statistics concern the overabundance of identical products rather than complementarity of products to boost intra-ASEAN trade. Three or four members of ASEAN produce as much as 70 to 80 per cent of world production of such as tin (Malaysia, Thailand, Indonesia and Singapore), while coconut oil and palm oil (mainly Malaysia and Philippines) and tapioca or manioc (mainly Thailand and Indonesia) are common export items from ASEAN countries. Energy resources such as gas and petroleum products are exported from Indonesia, Malaysia and the Philippines and to some extent refined and exported from Singapore [...]. In the industrial sectors of late, automobiles, electronics, television sets, VCRs, computers, etc., have begun to constitute significant export items from Singapore, Thailand and Malaysia".

${ }^{26}$ See S.CHATTERJEE, 'ASEAN economic co-operation: past, present and future', in A.BROINOWSKI (ed.), ASEAN into the 1990s (London:Macmillan,1990) at 66; J.-R.CHAPONNIERE, 'L'ASEAN: réussite politique ou échec économique?, 57 Economie Internationale (1994) at 50.

${ }^{27}$ On differences and similarities between ASEAN and the EC, see H.C.RIEGER, 'The Treaty of Rome and its relevance for ASEAN', 8 ASEAN Economic Bulletin (1991) 160-172; P.J.DAVIDSON, loc.cit n.5 at 599-601; COLIN Y.C.ONG, Cross-border litigation within ASEAN. The prospects for harmonization of civil and commercial litigation (The Hague-London-Boston: Kluwer, 1997) 33-113. 
commitments undertaken by ASEAN leaders in order to complement the creation of the free-trade area with other forms of economic integration in "non-border areas", such as those pertaining to an investment code, the protection of intellectual property and a services agreement, warrant this conclusion.

As regards the features of the economic co-operation among ASEAN countries, as is equally the case in other regional organizations in Asia, such as APEC, the keyword is "open regionalism": in short, regional co-operation to promote regional trade without discrimination against outsiders. ${ }^{28}$ The majority of academic economists assert that "open regionalism" has been embraced by the AFTA in its purest form. ${ }^{29}$ If this is correct, the AFTA would enhance regional economic liberalization in a manner consistent with the GATT/WTO rules on global liberalization. This is what the last part of the present article will try to demonstrate.

Meanwhile, it is remarkable that ASEAN members often adopt a common position within other international organizations. ${ }^{30}$ The Association thus presents itself as a single unit at the international level, showing a consider-

${ }^{28}$ See R.GARNAUT, 'ASEAN and the regionalization and globalization of world trade', 14 ASEAN Economic Bulletin (1998) at 216. Several definitions of "open regionalism" are available nowadays. A study of the Trade Policy Forum of the Pacific Economic Cooperation Council, quoted by B.BORA and C.FINDLAY, 'Introduction and overview', in B.BORA and C.FINDLAY (eds.), Regional integration and the Asia-Pacific (Melbourne: Oxford UP 1996) at 6, points out that "open regionalism" takes place in trade of goods and services when: "there is a movement towards free trade, that is, a reduction in barriers to trade compared to what might otherwise have been the case (binding existing tariffs would qualify); a reduction in barriers to trade is stimulated by and supported by a consensus between a group of countries located in the same region (e.g. East Asia, or the Pacific); the reduction in barriers to trade is applied country by country in a non discriminatory fashion but possibly not equally by every country in the group. Reductions in trade barriers occur in a number of sectors at the same time". In the opinion of IPPEI YAMAZAWA, 'On Pacific economic integration', 105 Economic Journal (1992) at 415, "open regionalism" is by definition an "outward-oriented regional arrangement" that shows the following peculiarities: "it is open, in the sense of not discriminating against the rest of the World; its primary policy focus is economic; it has coordinated decisionmaking based on consensus, rather than seeking to impose any supra-national authority on participants".

${ }^{29}$ See L LOW, 'The ASEAN Free-Trade Area', in B. BORA and C. FINDLAY (eds.), op.cit.n.28 at 197-206; J.PELKMANS, 'ASEAN and APEC: A triumph of the "Asian Way"?', in P.DEMARET, J.-F.BELLIS and G.GARCIA JIMENEZ (eds.), Regionalism and multilateralism after the Uruguay Round (Bruxelles: EIP, 1997), 199-230; M.G.PLUMMER, loc.cit.n.23 at 287; R.GARNAUT, loc.cit.n.28; D.K.DAS, 'Regional trading agreements - the contemporary scenario', 2 Journal of World Investment (2001) at 383.

${ }^{30}$ This is what happens de facto within the WTO, though ASEAN as such does not enjoy the status of member or of observer in the Organisation. On this issue, see P.J.DAVIDSON, loc.cit.n.5 at 597. 
able cohesion that is peculiar to economic and customs unions, but is quite unusual in the case of free-trade areas. ${ }^{31}$

\section{LEGAL INSTRUMENTS COMPLEMENTARY OR ADDITIONAL TO THE AFTA: THE ASEAN FRAMEWORK AGREEMENT ON SERVICES (AFAS) IN PARTICULAR}

During the Bangkok Summit of December 1995, the view was expressed that some bold measures were needed in order to accelerate further economic and political integration among ASEAN countries in the context of the establishment of the AFTA. These measures should serve to broaden the areas of economic co-operation by including services, ${ }^{32}$ intellectual property ${ }^{33}$ and a new industrial co-operation scheme. Consequently, the Bangkok Summit, in addition to the Amendment Protocols on the acceleration of the implementation of AFTA to 2003 and the expansion of the number of products subjected to tariff reduction ${ }^{34}$ produced a Framework Agreement on Intellectual Property Cooperation ${ }^{35}$ and a Framework Agreement on Services (AFAS). ${ }^{36}$

The former of these agreements envisages co-operation in the domain of intellectual property through the establishment of a system of ASEAN

\footnotetext{
An exception has, meanwhile, been introduced within the FAO as a particular concession to ASEAN: the right to take the floor has been given to the Association, although not all its members are members of the Organisation (the two non-member nations of FAO are Singapore and Brunei Darussalam). On this issue see R.FRID, op.cit.n.18 at 245-246. The position of ASEAN appears to have different features within the UN General Assembly. M.MARIN-BOSCH, Votes in the UN General Assembly, (The Hague: Kluwer, 1998) at 159, notices that: "It would be impossible to measure precisely the effects that trade and economic groupings have had on the voting patterns of their members. The ASEAN nations have had, at least since the seventies, a very high level of coincidence in General Assembly votes. And yet, except for some specific economic issues, they do not appear to seek, as do the members of the European Union, common voting positions beyond the co-ordination offered to them as members of the Group of 77 or the Non-Aligned Movement. Moreover, since 1991, differences among them have appeared, especially regarding social issues in general and human rights in particular. This trend has also become evident within the Non-Aligned Movement and between its members and the Western countries".

${ }^{31}$ But see the opposite opinion of M.MARIN-BOSCH, op.cit. n.30.

${ }^{32}$ On this issue, see ROBERT R.TEH, 'Preferential liberalization of services in ASEAN', in CHIA SIOW YUE and JOSEPH TAN (eds.), ASEAN in the WTO: challenges and responses (Singapore: ISEAS, 1996) 164-184.

${ }^{33}$ On the protection of intellectual property rights in ASEAN countries, see GEOFFREY YU, 'Issues in the protection of intellectual property rights in ASEAN: an international perspective', and S. TIWARI, 'Intellectual property rights: an ASEAN perspective', in CHIA SIOW YUE and JOSEPH TAN (eds.), op.cit.n.32 at 71-95 and 98-107, respectively.

${ }^{34}$ Supra, ns. 13, 14 and 15.

3535 I.L.M.(1996) 1074; 6 AsYIL (1996) 504.

3635 I.L.M.(1996) 1077; 6 AsYIL (1996) 507.
} 
patent and trademarks offices. ${ }^{37}$ The agreement merely reiterates the obligation of member states to implement intra-ASEAN intellectual property arrangements in a manner in line with their international intellectual property obligations: in particular, those arising from the WTO Agreement on TradeRelated Intellectual Property Rights (TRIPs). ${ }^{38}$

The Agreement on Services, on the other hand, aims at purposes beyond the GATS. ${ }^{39}$ Among its objectives is, according to Article 1(c) of the AFAS, the liberalization of trade in services "by expanding the depth and scope of liberalization beyond those undertaken by Member States under the GATS with the aim to realising a free trade area in services". Therefore, AFAS deserves special attention: a survey of its relevant provisions including an examination of its compatibility with GATS will be presented in section 5 of this paper. Such an investigation is further stimulated by the inclusion in the GATS (Article V),similarly to the GATT (Article XXIV) but not to the TRIPs, of specific rules applicable to regional integration. Apparently, provisions on regional arrangements were omitted from the TRIPs Agreement because the very broad obligation of national treatment contained in this treaty left little room for customs unions and free trade areas to provide preferential treatment to regional trade partners. ${ }^{40}$

ASEAN economies were severely affected by the financial and economic crisis of the years 1997-1998. ${ }^{41}$ In order to regain business confidence and enhance economic recovery in the region, the Member States decided to give priority to the promotion of ASEAN's industrial competitive edge and the encouragement of greater investment flows into the area. ${ }^{42}$

For this purpose, on 8 October 1998 the ASEAN governments concluded a Framework Agreement on the ASEAN Investment Area (AIA). Its main objectives are the increase of investments into ASEAN from both ASEAN and non-ASEAN sources, the improvement of competitiveness of ASEAN's economic sectors, and the reduction or elimination of regulations and con-

\footnotetext{
${ }^{37}$ For a detailed description of this agreement, see M.BLAKENEY, 'The role of intellectual property law in regional commercial unions', 1 The Journal of World Intellectual Property (1998) at 700; M.BLAKENEY and M.WILLIS, 'Intellectual property and regional trade arrangements in Europe, Asia and the Western Hemisphere', 4 International Trade Law \& Regulation (1998) at 75.

38 See Art. 2 of the ASEAN Framework Agreement on Intellectual Property Cooperation.

39 See COLIN Y.C.ONG, op.cit.n.27 at 65.

${ }^{40}$ See Regionalism and the world trading system (WTO, Geneva 1995) at 60-61; T.EINHORN, 'The impact of the WTO Agreement on TRIPs on EC Law: a challenge to regionalism', in P MENGOZZI (ed.), International trade law on the $50^{\text {th }}$ anniversary of the multilateral trade system, (Milano: Giuffrè, 1999) at 541.

41 See supra, n.1.

42 On the implications of AFTA for the investment flows and trade patterns in the region, see PREMA-CHANDRA ATHUKORALA and J.MENON, 'AFTA and the investment-trade nexus in ASEAN', 20 The World Economy 2 (1997) 159-174.
} 
ditions that may impede the implementation of investment projects in ASEAN. ${ }^{43}$

It is to be noted that promotion of ASEAN industrial competitiveness had also been sought in 1996 through the enactment of a new form of industrial cooperation scheme (ASEAN Industrial Cooperation (AICO) Scheme $)^{44}$ replacing the ASEAN Industrial Joint Ventures Scheme.$^{45}$ In short, the AICO Scheme encourages joint manufacturing industrial activities between ASEANbased companies, granting to AICO products a preferential tariff rate in the range of zero to five per cent.

The AFTA is also complemented by an apposite dispute settlement mechanism. A special Protocol on Dispute Settlement Mechanism implementing Article 9 of the Framework Agreement on Enhancing ASEAN Economic Cooperation, providing for the future designation of an appropriate body for the settlement of disputes, was signed on 20 November $1996 .{ }^{46}$ The mechanism may pass through five stages, that is to say, consultations, diplomatic means, recourse to the Senior Economic Officials Meeting (SEOM), establishment of Panels, and appeal to the ASEAN Economic Ministers (AEM).$^{47}$

\section{THE NOTIFICATION OF THE AFTA UNDER THE ENABLING CLAUSE}

The notification of the 1992 agreements establishing the AFTA was addressed to the GATT Contracting Parties requesting that these agreements be examined in the light of the Enabling Clause. ${ }^{48}$ The request was based on the argument that the arrangements in question constituted an integral part of the 1977 Agreement on ASEAN Preferential Trading Arrangements already

\footnotetext{
43 The 1998 Framework Agreement on the AIA, The ASEAN Document Series of 1998-1999 (www.aseansec.org.) reiterates (in its preamble) the commitments of the member states to the 1987 ASEAN Agreement for the Promotion and Protection of Investments and its 1996 Protocol.

${ }^{44}$ Basic Agreement on the ASEAN Industrial Cooperation Scheme, Singapore 27 April 1996, The ASEAN Document Series of 1996-1997 (www.aseansec.org.)

${ }^{45}$ Supra, n.3.

46 The ASEAN Document Series of 1996-1997 (www.aseansec.org.). Note that the Dispute Settlement Mechanism is to cover disputes arising from the interpretation or application of the 47 agreements listed in Appendix 1 to the Protocol, and future ASEAN economic agreements (Art.1.1 of the Protocol).

${ }^{47}$ For an analysis of the institutional framework and the procedural aspects of the ASEAN Protocol on Dispute Settlement Mechanism, see R.MOHAMAD, 'ASEAN's Protocol on Dispute Settlement Mechanism: a rule-based or political approach', International Trade Law \& Regulation 2 (1998) 47-54. On the brevity of the Protocol on Dispute Settlement Mechanism, with the intention of promoting, instead, the establishment of a regional arbitration centre, see PEARLIE M.C.KOH, 'Enhancing economic co-operation: a regional arbitration centre for ASEAN?', 49 ICLC (2000) 390-412.

${ }^{48} \mathrm{~L} / 7111$ (30 October 1992).
} 
notified in $1979 .{ }^{49}$ By virtue of this precedent, it was assumed that the usual examination carried out by the Committee on Trade and Development (CTD) in compliance with paragraph 4 of the Enabling Clause would take place. The GATT Contracting Parties expressed formally no objection to the above request, although some countries (the US, the EC and the Nordic countries) showed some concern and advanced the proposal that a notification be sent to the Council in order that the agreements be examined fully on their implications for all GATT Contracting Parties. ${ }^{50}$ Informal consultations took place on this point, resulting in the conclusion that, at that time, a free-trade area was only an aspiration. Since then, the ASEAN countries have continued to submit to the CTD at least annual information on their agreement. ${ }^{51}$

None of the reporting on the part of ASEAN has so far provoked any close investigation by the CTD. This is the conclusion to be drawn from the records of the meetings of this body. ${ }^{52}$ This attitude of the CTD is not surprising, considering that the substantive requirements of the Enabling Clause for regional arrangements entered into among less-developed contracting parties within the GATT/WTO framework are extremely flexible and even vague. The Enabling Clause in fact prescribes that any differential and more favourable treatment provided by those regional arrangements "shall be designed to facilitate and promote the trade of developing countries and not to raise barriers to or create undue difficulties for the trade of any other (GATT) contracting parties" and that it "shall not constitute an impediment to the reduction or elimination of tariffs and other restriction to trade on a most-favoured-nation basis".

As will be pointed out in section 4 of this paper the requirements of the Enabling Clause are less strict than those provided for in both Article XXIV of the GATT and in the Understanding on its interpretation. For instance, regarding the liberalization of trade among the Contracting Parties of a regional agreement, the requirements allow the exchange of preferences on a sub-set of products, and the partial reduction, rather than elimination, of

49 L/4581 (1 November 1977); Report of the Working Party adopted on 29 January 1979, L/4735; Decision of the CONTRACTING PARTIES of 29 January 1979, L/4768, BISD 26S/321 and 224, respectively; L/6569 (12 October 1989).

so See the communication received from the United States, L/7175 (28 January 1993).

51 See, for instance, L/7111/Add.1 (16 July 1993); L/7307 (29 Oct.1993); L/7307/Rev.1 (18 November 1993); L/7491 (27 June 1994); L/7546 (2 November 1994); L/7546/Add.1 (3 November 1994).

52 See, for instance, Report of the Committee on Trade and Development to the CONTRACTING PARTIES, L/7567 (9 December 1994), BISD 41S/97, which merely relates that "[t]he Committee also had before it notifications received from the ASEAN Member States (L/7491, and L/7546 and Add.1)" (par.2), and that "[t]he Committee took note of the notifications concerning the GSP schemes and of those received from the ASEAN Member States" (par.3). However, the control on the part of CTD had been a little more thorough when examining the first report on AFTA (L/7111). See Report of the Committee on Trade and Development to the CONTRACTING PARTIES, L/7124, of 3 December 1992, in BISD 39S/13, paras. 29-32. 
trade barriers. This immediately raises questions as to the adequacy of the required notification of arrangements made under the clause and, in particular, as regards which of the WTO Members are entitled to benefit from it.

Thus, it can be argued that, while the approval by the GATT Contracting Parties of the 1977 ASEAN preferential arrangements under the clause was legally and politically grounded, "the economic position of the ASEAN Member States has changed since that time: the status of Singapore as a developing country is certainly questionable, and other ASEAN member-states are also rapidly reaching the point where their claim to this status will be untenable". ${ }^{53}$

\section{APPLICATION EX HYPOTHESIS OF ARTICLE XXIV OF THE GATT TO THE AFTA}

While, from a legal point of view, questions of compatibility of the AFTA with the GATT/WTO system are perhaps answered through the Enabling Clause (and, potentially, Article V paragraph 3 of the GATS), this should not preclude a further examination. Above all, it is interesting to verify whether the creation of a free-trade area amongst ASEAN Member States does or does not satisfy the requirements laid down in Article XXIV of the GATT and thus, by analogy, those listed in Article V paragraph 1 of the GATS. Since a developed country cannot, on the basis of the Enabling Clause $^{54}$ participate in a free-trade area, a free trade area comprising both developing and developed countries should comply with the provisions of Article XXIV of the GATT in order to be in line with the GATT/WTO. The letter and spirit of the reference in paragraph 2 item (c) of the Enabling Clause to mutual "regional or global arrangements entered amongst less-developed contracting parties" would hardly be compatible with its application to regional arrangements including both developed and less-developed economies. Even though the Clause allows a developed country to accord preferences to trade originating from developing countries (paragraph 2, item (a)), it certainly does not allow the reverse, i.e., preferential treatment accorded by a developing country to trade coming from a developed country. However interpreted, the Enabling Clause may thus allow an arrangement to "raise barriers or to create undue difficulties for" world trade, in spite of its explicit preclusion in paragraph 3 item (a). Thus, as ASEAN Member States reach developed country status, the legal framework of AFTA will have to be changed to bring it into conformity with the general rules of the multilateral trading system. ${ }^{55}$

\footnotetext{
53 See P.J.DAVIDSON, loc.cit.n.5 at 607.

${ }^{54}$ Arguments leading to this conclusion, see supra n.6.

55 See P.J.DAVIDSON, loc.cit. n.5 at 608.
} 
Such a new approach to regional arrangements notified under the Enabling Clause was already adopted with regard to the MERCOSUR Agreement. In this case it was indeed decided that the customs union forming the Mercado Comun del Sur be examined not only in the light of the Enabling Clause but also from the perspective of Article XXIV. ${ }^{56}$ Under the resulting compromise solution, not in itself considered as setting a precedent, the agreement was monitored both by a Working Party established within the CTD and by the Committee on Regional Trade Agreements (CRTA).

Created in 1996 by a decision of the WTO General Council, ${ }^{57}$ the CRTA is charged with monitoring all preferential trade arrangements among WTO members. ${ }^{58}$ The functions of the CRTA overlap with, but do not replace, the special tasks of the Council on Trade in Goods (CTG), the Council on Trade in Services (CTS), and those of the CTD. Given its general competence ratione materiae, that is to say, its jurisdiction over agreements notified under Article XXIV of the GATT, Article V of the GATS or the Enabling Clause, priority will here be given to the practice of the CRTA in this examination into the compliance of the AFTA with the GATT/WTO rules.

The present section discusses the conformity of AFTA rules on trade in goods with the GATT/WTO; the following section compares the provisions of AFAS with those of Article V paragraph 1 of the GATS. Thus, other possible conflicts that may come to light between the rules of AFTA and GATT/WTO, such as in the field of intellectual property or dispute settlement, will not be addressed. ${ }^{59}$

Article XXIV of the GATT deals with free-trade areas in a less severe way than customs unions. The main reason for this distinction lays on the application within a customs union of a single tariff towards goods imported

56 Decision of the GATT Contracting PARTIES L/7124 of 3 December 1992, BISD 39S/13.

57 WT/L/127 of 7 February 1996.

${ }^{58}$ On the CRTA, see A.FABBRICOTTI, 'Gli accordi di integrazione economica regionale ed il GATT/ OMC. I parametri normativi e l'opera del CRTA', 14 Diritto del Commercio Internazionale 2 (2000), 281-327; 'Gli accordi di integrazione economica regionale ed il GATT/OMC. L'attivazione del regolamento delle controversie', 15 Diritto del Commercio Internazionale 4 (2001), 793-810.

59 States participating in a regional arrangement on trade in goods are invited by the CRTA to supply information on procedures for dispute settlement and on the relationship between the notified agreement in question and other arrangements. See Standard Format for Information on Regional Trade Agreements, WT/REG/W/6 (15 August 1996) para.III items 3 ("Dispute settlement procedures - Description of the mechanisms provided for resolving disputes among parties to the Agreement, and its relationship with intergovernmental dispute settlement instruments entered into by the parties under other bilateral, plurilateral and/or multilateral agreements") and 4 ("Relation with other trade agreements - Information relating to whether or not the Agreement establishes any specific relation with other bilateral, plurilateral and/or multilateral trade agreements"). During the CRTA meeting of 29-31 July 1996, the Chairman, speaking on his personal behalf, explained that "the submission of information which was not required specifically under Article XXIV: 5 was useful not only for reasons of transparency but also for understanding the dynamics of the agreement and delegations should feel encouraged to do so". See WT/REG/M/3 (29 August 1996) item C para.7. 
from outside the union. Since AFTA is a free-trade area, only paragraphs 4, 8(b) and 5(b) and (c) of Article XXIV will be taken into consideration. ${ }^{60}$

\subsection{The legal significance of Article XXIV paragraph 4}

According to Article XXIV paragraph 4, the creation of a free-trade area is "desirable" as long as its purpose is "to facilitate trade between the constituent territories and not to raise barriers to the trade of other contracting parties (GATT parties/WTO Members) with such territories". Given the vagueness of this language, there has been a continuing debate among jurists as to whether paragraph 4 is legal or political in its nature. The view has been expressed that, from a legal point of view, paragraph 4 has the value of a preamble: hence, it has a merely declaratory character and does not produce any direct and compulsory effect. ${ }^{61}$ This leads to the major conclusion that Article XXIV does not entail tests other than those provided for in paragraphs 5-8.

Since the analysis will hereinafter focus on the last-mentioned paragraphs, it should be stressed that ASEAN Member States have always underlined both in public statements and in agreements concerning AFTA the preeminence of the GATT rules. Furthermore, they have in particular confirmed their will to maintain unchanged the trading relations with third states. ${ }^{62}$

As described above, AFTA embraces and promotes "open regionalism" on account, among other reasons, of the non-complementary nature of the goods produced by its member states. In this context it is most relevant to recall the 1966 GATT Working Party report on "EEC Association Agreements with African and Malagasy States and Overseas Countries and Territories". It was noted in this report that "even if a free-trade area arrangement [...] met all the more specific requirements of Article XXIV, it was unlikely, given that the parties to the Arrangement tended to produce entirely different products, to satisfy the general requirement of paragraph 4 of the Article that free-trade arrangements should be designed to create new trade between the parties and not to divert existing trade". ${ }^{63}$ As a logical consequence, the diversity in productive sectors singled out by the Working Party as an example

\footnotetext{
${ }^{60}$ The order of listing and treatment of these paragraphs follows from the fact that para.8(b) contains a definition of free-trade area; its provisions should therefore be discussed before those of para.5. The same, R.S.IMHOOF, Le GATT et les zones de libre-échange (Genève: Georg, 1979) at 57.

${ }^{61}$ See A.FABBRICOTTI, loc.cit. n.58 (2000) at 299.

${ }^{62}$ This corresponds to the results of an investigation into the intentions of ASEAN leaders in AFTA, carried out between 1 January and 7 October 1996 for The Straits Times (with its reputation of having the most extensive coverage of ASEAN affairs) and the Far Eastern Economic Review. See also M.G.PLUMMER, 'Regional economic integrations and dynamic policy reform: the "special" case of developing Asia', 4 Asia-Pacific Development Journal (1997) at 18.

${ }^{63}$ Report of 4 April 1966 (L/2441), in Analytical Index: Guide to GATT Law and Practice, 6th edn. (Geneva:1994) at 74.
} 
of non-conformity to paragraph 4, and thus to Article XXIV in general, would presumably not be contended in respect of AFTA Member States.

\subsection{The "substantially all the trade" requirement}

The main condition required in Article XXIV paragraph 8(b) is that "substantially all the trade" between Member States of the free trade area concerned be affected by liberalization. Much has been said about the meaning of the expression "substantially all" and, in particular, on whether a quantitative (in number of products) or a qualitative (in number of productive sectors) criterion should be applied for this requirement to be satisfied. ${ }^{64}$ The practice of the CRTA shows that the issue is still controversial. ${ }^{65}$ The agricultural sector seems to constitute a substantial obstacle to a settlement of the disagreements: industrialized countries tend to refuse to extend reduction or abolition of tariffs to agricultural products while developing countries urge for a liberalization of the sector.

Turning attention to the AFTA, it would appear that the (Bangkok) arrangements of 1995 should be seen in connection with the "substantially all the trade" requirement. The arrangements had subjected unprocessed agricultural products to tariff reduction. Besides, products that, according to the 1992 CEPT-AFTA Agreement, were temporarily excluded from the scheme of tariff reduction were to be progressively liberalized before 1 January 2000. It now seems clear that these amendments were needed in order to adhere to Article XXIV paragraph 8(b) of the GATT. To this end, ASEAN Member States applied both the qualitative criterion, that of liberalizing the agricultural sector, and the quantitative criterion, of liberalizing almost all the products.

\subsection{The prohibition to increase tariffs or to restrict other regulations of commerce with third parties}

According to Article XXIV paragraph 5(b) of the GATT, the duties and other regulations of commerce maintained in each Member State of a given free-trade area and applicable to the trade with third countries shall not be higher or more severe than those existing prior to the creation of this free-

\footnotetext{
${ }^{64}$ See, inter alia, J.H.JACKSON, World Trade and the Law of GATT (Indianapolis-Kansas City-New York: Bobbs-Merrill, 1969) at 607 et seq.; IMHOOF, op.cit. n.60 at 65 et seq.; J.HUBER, 'The practice of GATT in examining regional arrangements under Article XXIV', 19 Journal of Common Market Studies (1981) 282; D.CARREAU, T.FLORY and P.JUILLARD, Droit international economique, 3rd edn. (Paris: LGDJ, 1990) at 124; Regionalism and the world trading system, supra n.40 at 13 et seq.

${ }^{65}$ See, e.g., WT/REG/W/16 (26 May 1997) paras.40-44, and WT/REG/W/21/Add.1 (2 December 1997).
} 
trade area. Apparently, this condition does not raise particular questions; it seems simply to repeat the obligations, concerning tariffs concessions, already binding on all WTO members from the entry into force of Articles XXVIII and XXVIII bis GATT. ${ }^{66}$ The real meaning and purpose of paragraph 5(b) becomes clear, however, when it is compared to the preceding paragraph 5(a), which applies to customs unions. The focus here is on the effects on trade with third states that would result from the introduction of a single customs tariff, which "shall not on the whole be higher or more restrictive than the general incidence of the duties and regulations of commerce" applicable in the member states prior to the formation of the customs union.

Free-trade areas are more limited in scope than customs unions, since they are created for the mere purpose of trade liberalization among member states. The risk of these countries' attempts to compensate for the abolition or reduction of tariffs on goods produced within the area by raising tariffs towards products from outside does indeed exist and should not be underestimated. Hence, not only is the prohibition against acting in this discriminatory way affirmed by paragraph 5(b), but the escape clause of Article XXIV paragraph 6 , consisting of new tariff negotiations with third states, covers customs unions only and does not apply to free-trade areas. ${ }^{67}$

It seems that the discussion on the compliance of the AFTA with paragraph 5(b) should start with the obvious point that, with respect to relations with the outside world, this free-trade arrangement implies not the adoption of a single customs tariff, but the reduction of customs tariffs on the products of other member states to less than five per cent.

Nevertheless, it should be asked whether this internal provision can, even though only in an indirect manner, affect the commerce of each of the ASEAN countries with third states. Statistics show that trade of ASEAN member states with countries outside the free-trade area continued to increase after the decision on the formation of AFTA had been taken. ${ }^{68}$ Presumably, this result was achieved thanks to the "outward-orientated" policy of ASEAN

${ }^{66}$ T.FLORY, Le GATT, droit international et commerce mondial (Paris: LGDJ, 1968) at 63; R.S.IMHOOF, op.cit. n.60 at 87.

${ }^{67}$ See, for example, the Japanese critical remarks during the examination of the Interim Agreement between the European Communities and Poland within the CRTA: "As everyone was aware, Poland had raised import tariffs from 15 per cent to 35 per cent after signing the Agreement and later given a duty-free quota to the EC. This had caused damage to the industries of many countries, including Japan. In 1992-1993 Japanese car sales to Poland dropped by 40 per cent [...]. Article XXIV:5(b) should be interpreted strictly. Thus, the Parties should not have raised duties. Raising the tariff right after the Agreement had been signed was not consistent with Article XXIV, or, more generally, the principles of the WTO." WT/REG18/M/2 (3 October 1997) para.12.

${ }^{68}$ See, for instance, the tables (9.2 and 9.3, originating from the EC in 1995) supplied by D.J.LANGHAMMER, loc.cit. (Europe's trade, etc.) n.18, concerning the increasing percentage of imports in ASEAN member states of goods originating in the European Union, the USA and Japan, during the years 1991-1994. 
and the concern of its members for restrictions on trade with third parties being introduced as a reaction to the reduction of tariffs within the region. ${ }^{69}$

As examined above, such a policy, inspired by the idea of "open regionalism", ${ }^{70}$ is closely connected with several features of the Association, such as the gap in economic and political development between member states, and the non-complementary nature of their productive sectors. Hence, the volume of trade (the exports, in particular) between each of the ASEAN Members and third states is bigger than the volume of trade between the ASEAN Member State in question and all other participants to the free-trade arrangement. ${ }^{71}$ It is thus obvious that ASEAN Member States would never jeopardise their relations with trading partners outside the free-trade area by creating new and stricter barriers.

Closely related to the above is the question whether rules of origin ${ }^{72}$ fall within the "other regulations of commerce", the restriction of which is prohibited by paragraph 5(b). According to the practice of the CRTA, this question should be answered in the affirmative, although a minority of states still consider rules of origin as mere criteria for the administration of intraregional trade flows and, consequently, of no relevance for commerce with the outside world. ${ }^{73}$

The AFTA rules of origin need to be addressed. The aim of ASEAN (Member States) to keep the AFTA market open to the world outside the area seems confirmed by the rules of origin that are at the basis of CEPT. A provision such as that in Article 2 paragraph 4 of CEPT, stating that AFTA origin is already ascribed to products even if no more than $40 \%$ of their content originates from a Member State, indeed shows a tendency to allow third states relatively easy access to the preferential treatment. ${ }^{74}$ On the other

69 This attitude was apparent in Art.1 of the Framework Agreement of 1992: "Member States shall endeavour to strengthen their economic cooperation through an outward-looking attitude so that their cooperation contributes to the promotion of global trade liberalisation". See also supra n.62.

${ }^{70}$ On "open regionalism" in general see supra, section 1 (especially n.28). On application of "open regionalism" to ASEAN, see P.DRYSDALE, A.ELEK and H.SOESASTRO, 'Open regionalism: the nature of Asia Pacific integration', in P.DRYSDALE and D.VINES (eds.), op.cit. n.7 p.103 et seq.

${ }^{71}$ On this issue, see D.A.DEROSA, Regional trading arrangements among developing countries: the ASEAN example (International Food Policy Research Institute Report No.103, at 25.

72 Through the use of very complex percentage coefficients, these rules determine the products that should be considered as originating in a particular region and that are, by virtue of the certificate of origin, eligible for liberalisation: especially in free-trade areas, these rules have an immediate and considerable impact on the direction of production and on trade flows.

${ }^{73}$ See A.FABBRICOTTI, loc.cit. n.58 (2000) at 312. The issue has been discussed several times in the GATT Working Parties, now replaced by the CRTA. See Guide, op.cit. n.63 at 746 et seq.

${ }^{74}$ By way of comparison, the percentage of 62,5 applied by NAFTA to automobiles indicates a higher degree of protectionism. On this topic, see F.M.ABBOTT, Law and policy of regional integration: The NAFTA and Western Hemispheric integration in the World Trade Organization system (Dordrecht-Boston-London: Nijhoff, 1995) at 65. For a comparison of different rules of origin in customs unions and free-trade areas, see D.PALMETER, 'Rules of origin in customs unions and free 
hand, the need to promote the localization of the manufacturing process seems already to have been met through the statement that "products worked on and processed as a result of which the total value of the materials, parts or produce originating from non-ASEAN countries or of undetermined origin used does not exceed $60 \%$ of the value of the product produced or obtained" are also eligible for preferential concessions, provided that "the final process of the manufacture is performed within the territory of the exporting Member State".

\subsection{The schedule for establishing the AFTA}

According to Article XXIV paragraph 5(c) of the GATT, any interim agreement leading to the formation of a free-trade area shall include a plan and schedule for the establishment of such an integrated area "within a reasonable length of time". Paragraph 3 of the 1994 Understanding on the Interpretation of Article XXIV later clarified that the "reasonable length of time" should only in exceptional cases exceed ten years. It is thus arguable that the decision taken at the Bangkok Summit to advance the effective formation of the AFTA to 2003 was in fact an act of enforcement of this time-limit requirement. ${ }^{75}$

\section{THE COMPATIBILITY OF THE AFTA WITH THE GATS}

It remains to be considered whether the ASEAN Framework Agreement on Services (AFAS) is consistent with the rules concerning regional integration set out in the General Agreement on Trade in Services (GATS) ${ }^{76}$

The present paper has already demonstrated a certain tendency of the AFTA to comply with the prevailing multilateral trade rules applicable to developed countries. This is reinforced by reading the AFAS in the light of Article V paragraph 1 of the GATS, dealing with the liberalization of trade in services among some of the Parties to the General Agreement. ${ }^{77}$ This reading clearly shows that Article III of the AFAS, which contains the essence of the whole Framework Agreement, was conceived in order to comply with the requirements listed in the GATS provision. ${ }^{78}$

trade areas', in K.ANDERSON and R.BLACKHURST (eds.), Regional integration and the global trading system (New York: Harvester, 1993) 326 et seq.

75 See L.LOW, loc.cit. n.29 at 199.

76 On AFAS, see supra, section 2.

${ }^{77}$ For a detailed analysis, see NAGAVALli ANNAMALAI, 'ASEAN Framework Agreement on Services and GATS - a textual analysis', International Trade Law \& Regulation 2 (1998) 61-67.

${ }^{78}$ On this topic, see NAGAVAlli ANNAMALAI, 'Liberalisation of trade in services in ASEAN developments and comments', International Trade Law \& Regulation 2 (1998) at 58. 
Let us compare the two statements. According to paragraph 1 of Article $\mathrm{V}$ of the GATS, a preferential agreement on trade in services shall have "substantial sectoral coverage" and shall provide for the absence or elimination of "substantially all discrimination" between the parties in the sectors covered through the "elimination of existing discriminatory measures and/or prohibition of new or more discriminatory measures". In line with these requirements, ASEAN member states undertook in Article III of the AFAS to "liberalise trade in services in a substantial number of sectors within a reasonable time-frame by: (a) eliminating substantially all existing discriminatory measures and market access limitations amongst Member States; and (b) prohibiting new or more discriminatory measures and market access limitations".

There is yet another coincidence. Article V paragraph 6 of the GATS prescribes that: "A service supplier of any other Member that is a juridical person constituted under the laws of a party to an agreement [...] shall be entitled to treatment granted under such agreement, provided that it engages in substantive business operations in the territory of the parties to such agreement". Although using a negative formulation, Article VI of the AFAS provides the same when asserting that " $[\mathrm{t}] \mathrm{he}$ benefits of this Framework Agreement shall be denied to a service supplier who is a natural person of a non-member State or a juridical person owned or controlled by persons of a non-member State constituted under the laws of a Member State, but not engaged in substantive business operations in the territory of Member State(s)". It is to be noted that those instrumental in drafting the AFAS could in fact have ignored the requirement of "substantive business operations" and by way of justification invoke paragraph 3(b) of Article V of the GATS; this provides that, in the event of an agreement exclusively involving developing countries, "more favourable treatment may be granted to juridical persons owned or controlled by natural persons of the parties to such an agreement".

The AFAS had at the time of writing not yet been notified to the WTO. In view of the foregoing, it appears that there is no reason to suspect that ASEAN Member States would try to evade the control of the CRTA under paragraph 1 of Article V of the GATS. Such a suspicion does not seem to be justified given, among other factors, that the text of the AFAS was elaborated in collaboration with WTO legal advisers. ${ }^{79}$

79 Rather, one should wonder if the ASEAN member states would, in notifying the AFAS to the WTO, invoke the cover of Art.V para.3 GATS, which provides a special treatment for economic arrangements among developing countries. The provision corresponds, with special reference to trade in services, to what the Enabling Clause is for trade in goods. It reads: "(a) Where developing countries are parties to an agreement of the type referred to in paragraph 1 [i.e. economic integration agreement], flexibility shall be provided for regarding the conditions set out in paragraph 1, particularly with reference to subparagraph (b) thereof, in accordance with the level of development of the countries concerned, both overall and in individual sectors and sub-sectors; (b) Notwithstanding paragraph 6 , in the case of an agreement of the type referred to in paragraph 1, involving only 


\section{FINAL REMARKS}

At the very beginning, the AFTA was probably not conceived to be consistent with Article XXIV of the GATT. Rather, it was projected by relying on the exception granted in favour of developing countries, allowing them under the Enabling Clause to conclude preferential trading agreements. Thanks to this exemption from Article XXIV, developing countries have enjoyed virtual "carte blanche" in their practice in the formation of free-trade areas or customs unions. Yet it is doubtful whether such a differential and preferential treatment has in fact helped the developing countries to integrate with the world economy or whether it has, on the contrary, retarded this integration. ${ }^{80}$ Whatever the case may be, the present study has shown that the ASEAN countries have departed from the practice under the Enabling Clause and have tried to bring the AFTA in conformity with the requirements of Article XXIV of the GATT. The 1995 amendments to the initial AFTA arrangements may have been made for this purpose and AFAS has been drafted to be in conformity with Article V paragraph 1 of the GATS. Consequently, both AFTA and AFAS appear in principle to be consistent with GATT/WTO rules concerning the creation of a customs union or a freetrade agreement among developed countries.

The concern of ASEAN over Article XXIV of the GATT and Article V paragraph 1 of the GATS may in fact have been for different reasons. One explanation may be found in the awkward position of some ASEAN Member States, as they became aware that they no longer fitted within the definition of "developing countries". This is supposedly the case with Singapore, an industrialised or newly industrialising country (NIC), ${ }^{81}$ whose growth of per capita gross national product is among the higher ones in the world. ${ }^{82}$ On the other hand, ASEAN Member States may have been persuaded that transparency would be the most effective means of conferring credibility and respectability upon the AFTA. Indeed, even if Article XXIV of the GATT and Article V paragraph 1 of the GATS are unable to prevent harmful prac-

\footnotetext{
developing countries, more favourable treatment may be granted to juridical persons owned or controlled by natural persons of the parties to such an agreement." On the special position of developing countries in the GATS, see A.A.KIPPEL, 'Special and differential treatment for developing countries', in T.P.STEWART (ed.), The World Trade Organization (Washington D.C.: American Bar Association, 1996) at 656 et seq.

${ }^{80}$ The latter conclusion is drawn, inter alia, by the Carnegie Endowment Study Group on International Trade, in its report entitled Reflections on Regionalism (Washington, 1997) at 30, and by T.N.SRINIVASAN, 'Regionalism and the WTO: is non-discrimination passé?', in A.O.KRUEGER (ed.), The WTO as an International Organization (Chicago-London: University of Chicago Press, 1998) at 330 .

${ }^{81}$ See D.A.DEROSA, op.cit n.71 at 15.

${ }^{82}$ Wherever these terms are defined, a country's status as "developed", "developing", or "leastdeveloped" is determined primarily with reference to its per capita gross national product (GNP). See A.A.KIPPEL, loc.cit. n.79 at 622.
} 
tices, they can at least provide legal cover and can confer a hallmark of transparency to a much higher degree than do the Enabling Clause and Article $\mathrm{V}$ paragraph 3 GATS, both of which are suspected of providing the means of avoiding the most-favourite-nation obligation. ${ }^{83}$ Besides, ASEAN Member States may have become increasingly self-confident and, consequently, optimistic about the outcome of WTO control under Article XXIV of the GATT and Article V paragraph 1 of the GATS.

The attitude and behaviour of ASEAN described above should be encouraged and commended among the participants in other regional arrangements notified to the WTO under the Enabling Clause. Success in this respect might be achieved by stressing that Article XXIV of the GATT and the Enabling Clause, on the one hand, and paragraphs 1 and 3 of Article V of the GATS on the other, are not mutually exclusive. ${ }^{84}$ This view has so far been held only in the case of MERCOSUR, though rather by way of exception than to be considered to have set a precedent. ${ }^{85}$

${ }^{83}$ See the Report, supra n.80.

${ }^{84}$ How the WTO should treat legally regional arrangements on trade in goods including both developed and less-developed economies as members is an issue currently under debate. Three options may be available: (1) the participating states may be requested to conform the RTA in question with the requirements of paragraphs 5 to 8 of Article XXIV GATT; (2) the member states of the arrangement concerned may be requested to notify these RTAs under both the Enabling Clause and Article XXIV GATT; (3) the RTAs in question may be treated in a special and flexible way, which could consist of either allowing different levels of liberalization amongst Contracting Parties; or applying internal rules differently; or introducing transition periods for some of the members; or compensating exemptions with special measures. The third option would appear to be the most appropriate in view of the diversity among the economies within such regional arrangements, as is AFTA. Flexibility is already topical in a number of regional arrangements characterised by diversity of the economies involved, like the Lomé Convention and the special measures applied to Mexico by NAFTA. The legal justification for this kind of arrangements is to be found in the differential treatment accorded to less-developed WTO member states, mainly under the cover of Part IV GATT or by resorting to Art.XXV, par.5 GATT (Waiver). However, since excessive differential measures may divert into protectionism, which is deemed to be detrimental to the cause of regionalism - that is to say to both regional liberalisation efforts and regional integration and co-operation - it seems desirable that new, balanced, solutions be studied and promoted. On this topic, see YoSH KODAMA, Asia Pacific economic integration and the GATT-WTO regime (The Hague, London and Boston: Kluwer, 2000) at 172.

${ }^{85}$ See supra, section 4, esp. n.57. 